\title{
Russia's Emergence as an International Conservative Power
}

\section{Russian Conservatism: An Ideology or a Natural Attitude?}

Paul F. Robinson

\author{
Paul F. Robinson \\ Graduate School of Public and International Affairs, University of Ottawa, Canada. \\ Professor
}

Scopus AuthorID: 57205126860

E-mail: paul.robinson@uottawa.ca

Tel: +44 (613) 5625800 ext 4174

Address: 120 University, Ottawa, Ontario, K1N 6N5, Canada

DOI: $10.31278 / 1810-6374-2020-18-1-10-37$

\begin{abstract}
Since Vladimir Putin's return to the presidency in 2012 it has become common to talk of a "conservative turn" in Russian politics. Various commentators argue that this ideological shift applies to external as well as internal politics, with Russia becoming an international conservative power. This article seeks to determine what being an "international conservative power" actually means for Russia, by means of an examination of four different variations of Russian conservatism-Orthodox/Slavophile conservatism, civilizational conservatism, isolationist conservatism, and state/official conservatism. It argues that these are not all fully compatible with each other. If Russia truly is emerging as a conservative international power, this could lead both Russia and the world in one of several different directions, depending on which version of conservatism comes to dominate. Overall, though, it seems likely that the result will be a pragmatic, moderate
\end{abstract}


variety of conservatism rather than the more radical versions associated with conservative ideologists.

Keywords: Russia, conservatism, international power, Orthodoxy, Slavophilism, civilizations, isolationism

ince Vladimir Putin's return to the presidency of the Russian Federation in 2012, it has become common to talk of a "conservative turn" in Russian politics (Engström, 2014, p. 356; Makarychev and Yatsyk, 2014, p. 2; Evans, 2015, pp. 401-402). Commentators argue that this ideological shift applies to external as well as internal politics, with Russia becoming an international conservative power. Putin is said to be "attempting to place himself at the vanguard of a new "Conservative International"' (Whitmore, 2013), and according to Glenn Diesen of the Higher School of Economics in Moscow, "Russia has emerged as an international conservative leader that stands up for traditional European culture, Christianity, traditional values, and the family. Russia has returned to its pre-communist role as the go-to country for Western classical conservatives" (Blinova, 2018).

This article seeks to determine what being an "international conservative power" actually means for Russia. This is necessary because the idea, while widely accepted, is not without problems. In the first place, the definition of conservatism is hotly disputed. If one takes Samuel Huntington's view of conservatism as a "positional ideology" (Huntington, 1957, p. 455), then conservatism contains no fixed values and its content varies substantially from place to place and from era to era. A conservative in a free market liberal democracy will be a free market liberal democrat; but a conservative in a communist society will be a communist. As the nineteenth century Russian philosopher Konstantin Leontyev put it, "everyone's conservatism is his own-the Turk's is Turkish, the Englishman's is English, and the Russian's is Russian" (Minakov, 2011, p. 22). In this view, conservatism is inherently national, and a conservative can be almost anything. This 
casts a certain amount of doubt on whether being an "international conservative power" is even possible. According to this interpretation, Russian conservatism is inevitably different from any other country's conservatism and thus non-exportable.

A second problem is that, as Paul Grenier points out, there is no single Russian conservatism. Instead, one needs to think of "varieties of Russian conservatism" (Grenier, 2015). Grenier lists three types. Another study identifies seven (Shchipkov, 2014), and yet another nine (Fedulov, 2015). There are substantial differences between, for instance, liberal conservatives and left-wing conservatives, and between ethno-nationalist conservatives and Eurasianist conservatives. It is also important to understand that the conservatism of the Russian state and its leading officials has historically been, and still is, very different from that of conservative philosophers. From the time of Nikolai Karamzin onwards, what one might call "intellectual conservatism" has to a large extent been an oppositional phenomenon, while the Russian state has tended to sideline conservative intellectuals. Consequently, as Leonid Polyakov comments, "conservatism in Russia has never turned into a real force, and all Russian conservatives have felt the tragedy of their alienation from power" (Polyakov, 2014, p. 46). When talking about Russia as a "conservative power" it is therefore necessary to draw a sharp distinction between state policy and the views of conservative philosophers.

Given these problems, the idea of Russia as an international conservative power needs exploring if it is to have any value as a means of understanding contemporary international affairs. To that end, this article will first define both conservatism and Russian conservatism and then examine the varieties of Russian conservatism. It will demonstrate that being an international conservative power can have several cultural and geopolitical meanings, not all of which are fully compatible with each other. If Russia truly is emerging as a conservative international power, this could therefore lead both Russia and the world in one of several different directions depending on which version of conservatism comes to dominate. Overall, though, it seems likely that the result will be a pragmatic, moderate variety of 
conservatism rather than the more radical versions associated with conservative ideologists.

\section{DEFINING RUSSIAN CONSERVATISM}

An immediate problem confronted by anyone researching the topic of conservatism is that conservatism has never been adequately defined. Perhaps the key to understanding the subject is recognizing that conservatism has what one Russian scholar calls a "binary nature" (Gorokhov, 2016). On the one hand, it is an ideology containing immutable values that transcend time and space. On the other hand, it is a "natural attitude" in favor of existing institutions, which manifests itself in different ways in different times and places, according to what the existing institutions happen to be (Huntington, 1957, p. 455). In practice, these two types of conservatism tend to exist side by side, creating tensions that are not easily reconciled.

In line with this logic, Michael Freeden argues that conservatism consists of two "core concepts"-first the "understanding of organic change" and second "a belief in the extra-human origins of the social order" (Freeden, 1996, p. 10). These two concepts do not fit easily together either. An "understanding of organic change" comes close to the "natural attitude" mentioned above and is by nature particularistic: it suggests that each society is different and should develop differently, and that there are no universally suitable social values or institutions. "A belief in the extra-human origins of the social order," by contrast, comes close to being an ideology, as it suggests that there are universal, usually God-given, values which transcend time and space. This contradiction between universalism and particularism can be very clearly seen in Russian conservatism. Russian conservatives of all types consistently claim that Russia is different from the West and that Western claims regarding universal human values are false. But the characteristic most often used to justify Russia's claim to difference is its Orthodox religion, which is said to be a bearer of universal truth.

Conservatives have sought to square this circle in three ways. The first is by claiming that Russia's particularity is that it is the repository of the universal truth. From this it follows that Russia must defend its 
separate identity for the benefit of mankind as a whole. The second has been to identify the universal good with the promotion of national diversity. This approach rejects universalism while at the same time preserving the idea that Russia has a universal mission. The third way involves abandoning the concept of universal mission and instead believing that the priority should be "Russia for the Russians."

The first of these strands of Russian conservatism is strongly associated with Orthodoxy and also draws heavily on Slavophile philosophy. The focus of this "Orthodox/Slavophile conservatism" is primarily cultural. The second strand derives from post-Slavophile thinkers such as Nikolai Danilevsky, as well as from Eurasianist ideas. It stresses that different civilizations may not rightly be judged against one another and could be called "civilizational conservatism." It is largely geopolitical in focus. The third strand overlaps to some degree with ethnic Russian nationalism and could be called "isolationist conservatism." It looks inwards rather than outwards.

All of these approaches represent strands of intellectual conservatism. As mentioned above, one must also consider what one might call "state" or "official" conservatism. In this, the interests of the state are paramount, and two of the most important concerns are stability and the avoidance of external and internal shocks. While the state may make use of ideological constructs in pursuit of its interests, ideology per se is not a decisive factor.

It should be noted that there is a considerable overlap between the four varieties of conservatism above. They represent broad trends rather than watertight categories. I shall now examine each of them in turn.

\section{ORTHODOX/SLAVOPHILE CONSERVATISM}

The idea that Russia has some holy mission associated with Orthodoxy is often said to date back to the sixteenth century monk Filofei of Pskov's coining of the phrase "Third Rome" to describe Moscow. In the early nineteenth century, the defeat of Napoleon's army by Russia in 1812, the leading role played by the Russian army in liberating Europe from French control, and the subsequent creation in 1815 of the Holy 
Alliance between Russia, Prussia, and Austria gave new impetus to this idea. Thus in an 1815 book one of Alexander's diplomats, Aleksandr Sturdza, argued that only Orthodoxy had remained true to Christian principles. The French Revolution had been God's punishment for the rationalism of Western Europe, but through the Holy Alliance, Russia could morally resurrect Europe as a whole (Minakov, 2011, p. 31).

Sturdza's argument was an early example of what became a common theme of Orthodox conservatism: the moral decline of the West and Russia's mission to save the West from itself by preserving religious faith and the true values of Christianity. This theme was taken up by writer Vladimir Odoevsky in his 1844 book Russian Nights. "The West is perishing!" he wrote, adding that "Sometimes during happy moments, Providence (...) nurses a nation which will have to show the way from which mankind has deviated and which will then occupy the first place among nations" (Odoevsky, 1997, p. 209). That nation, of course, was Russia.

The mid-nineteenth century Slavophiles, most notably Ivan Kireevsky and Alexei Khomyakov, embraced this sense of mission. Following Odoevsky, the Slavophiles argued that the West was decaying, but that its decay was spiritual not material. It followed that Russia's mission to save it was also spiritual. The Slavophiles identified two aspects of Russian spirituality which compromised Russia's contribution to humanity, both of which they associated with Orthodoxy"wholeness of spirit" and the untranslatable concept of sobornost. The former was a reaction to the supposedly one-sided rationalism of the West, the latter a reaction to its supposed individualism. By nurturing these special Russian spiritual characteristics, Russia would be able in due course to reintroduce them to the West and thereby rescue it from its moral decay (Rabow-Edling, 2006, pp. 42-44).

Slavophilism thus combined both elements of Freeden's definition of conservatism: a belief in organic growth and a belief in the extrahuman origins of the social order. It sought to reconcile the two by claiming that the universal was served by the preservation of the particular. A somewhat similar approach was adopted by adherents of the idea of "Orthodox patriotism" in the late nineteenth and early 
twentieth centuries. According to Orthodox patriotism, Russia was the "New Jerusalem," the land in which God's truth was preserved. As the curator of the universal idea, this gave Russia a missionary purpose (Strickland, 2013, p. 7, 73). Moving forward to the postSoviet era, in which Orthodoxy has undergone a significant revival, the basic philosophy remains the same: the West is decaying, suffering from excessive materialism, individualism, and rationalism. By contrast, Russia retains the Christian faith and its traditional values. This provides Russia with its international purpose. As John Burgess notes, "[The Orthodox Church] has come to the following conclusion: because Russia, often in spite of itself, has preserved Orthodoxy through the ages, the nation and its Church now have a special responsibility to demonstrate what is good and true not only for Russians but for humanity as a whole. Russia's greatness lies in preserving this vision of heaven on earth and offering it to the world" (Burgess, 2017, p. 14-15).

In Orthodox conservative thought this makes Russia the katechon, "that which stands on the bridge between the Antichrist and the world and which does not let the Antichrist into the world" (Engström, 2014, p. 368). As a manifesto entitled The Russian Doctrine, published by the Institute of Dynamic Conservatism in 2016, puts it, "The defense of civilization from barbarism, its assimilation, this is the first function of the katechon. (...) The katechon as an Orthodox kingdom defends Christians against forces hostile to the salvation of the soul" (Institute of Dynamic Conservatism, 2016, pp. 70-71).

In fulfilment of this mission, the Russian Orthodox Church has been reaching out to like-minded believers in other parts of the world. For instance, Christopher Stroop notes that "Russian conservatives were central to the founding and operations of the World Congress of Families (WCF), a Christian-dominated inter-confessional coalition of right-wing activists from around the world dedicated to defending what they call 'the natural family', that is, a nuclear family consisting of a married man and woman and their children" (Stroop, 2016, p. 4). Stroop remarks that "it would be a mistake (...) to look at Russian social conservatism as essentially confined to Russia itself” (Stroop, 
2016, p. 5). Rather it is something which Russians are actively seeking to export.

This reflects the fact that the Orthodox/Slavophile tradition views Russia as part of a wider Christian civilization. Taking this logic further, rather than seeing the main political struggle of the modern era as being that between Russia and the West, some prefer to see it as being that between the forces of liberalism and the forces of tradition within both communities. Accordingly, Russia and the West are not enemies, and conservatives in both share common foes. One prominent proponent of this mode of thought is Natalya Narochnitskaya, who comments that "the main dilemma is 'conservative Europe versus postmodern Europe', and Russia is on the side of conservative Europe" (Narochnitskaya, 2015, p. 230). "Russia's future is Europe's future," Narochnitskaya asserts $(2015$, p. 35).

Finally, it should be noted that Orthodox/Slavophile conservatism also has an economic and social element, which brings it into alliance with what is often called "left conservatism." This form of conservatism favors economic policies which are generally considered left-wing, such as a large role for the state in the economy and a well-developed welfare state. As Alexander Shchipkov comments, left (or as it is sometimes called, "social") conservatism is founded on the principle of "social justice" and the Orthodox-Slavophile "concept of sobornost" (Shchipkov, 2017, pp. 52, 54). Sergei Glazyev similarly argues that "at the foundation of our worldview lies the imperative of social justice" associated with "collectivism and sobornost"' (Glazyev, 2014a, pp. 61, 62). Glazyev states that Russia needs a new model of development, founded on "a social-conservative synthesis, uniting the system of values of world religions with the achievements of the social state and the scientific paradigm of steady development" (Glazyev, 2014b).

The question then arises whether this form of conservatism has any effect. Does it actually make Russia an international conservative "power"? Certainly, some Russian conservatives hope that it will. Oleg Avdeev, for instance, writes that, "Conservatism can and already is becoming the ideal ideological basis of both Russia and its soft power" (Avdeev, 2014, p. 70). Avdeev continues: "Conservatism has been and 
still is one of the most influential forces in the contemporary West, through which Russia can find a fair number of unexpected allies of its conservative turn. Thus, although many of the conservative political measures taken by the Russian authorities in the last one and a half years have provoked a predictably negative reaction, they've also been met with sympathy by many" (Avdeev, 2014, p. 72).

This sympathy, Avdeev believes, will enable Russia to win friends abroad, among both the general population and the elites, and will thereby enable it to better defend itself and its interests. To some extent this has proven to be the case, as some conservatives in the Western world have certainly expressed sympathy for Russia’s defense of "traditional values." Most notably, one-time American presidential candidate Patrick Buchanan penned an article entitled "Is Putin One of Us?" praising the Russian president's defense of "traditional values" (Buchanan, 2013). According to John Lloyd and Darya Litinova, Russia's conservative message has broad, enduring, and even increasing appeal among disgruntled Western social conservatives. And not just in the West. Many of the states to which Russia is reaching outin the Middle and Far East, in Africa, in South America-share the "traditional values" Putin claims for Russia. They are their traditional values too (Lloyd and Litinova, 2018).

Determining the breadth of this appeal is difficult. While Lloyd and Litinova may be correct about its attractiveness in the developing world, in the West the likes of Buchanan represent the political fringe, not the mainstream. Russia's defense of traditional values has been more often seen as reactionary and inherently hostile to Western liberal democracy. Whether this form of "soft power" has helped or harmed Russia remains to be seen.

There is a sense, though, in which that does not matter. Orthodox/ Slavophile conservatism is at heart a cultural religious project and not a political one. It should not be judged by whether it enhances the power of the Russian state but by whether it succeeds in supplanting contemporary secular materialism with a more traditional religious understanding of the universe. Nevertheless, it is true that that has political ramifications. For instance, the ideas proposed by 
Narochnitskaya above, that Russia is part of a wider Christian civilization and that Russian and Western conservatives are bound together against common enemies (liberalism, post-modernism, moral relativism, etc.), lead to the conclusion that Russia should seek allies among like-minded people abroad, forging links with sympathetic conservative political, social, and cultural forces in the West and elsewhere. This explains both the connections of the Russian Orthodox Church with groups such as the WCF and the ties established by the Russian state with various populist parties in Western Europe. The ultimate aim is not Russia's separation from Europe but a common European future of which Russia is an integral part.

Certain policy preferences also emerge out of left conservatism. While this is largely domestically oriented, it does have international implications. In particular, left conservatives tend to be skeptical of the benefits of globalization and international (especially American) capital. Glazyev, for instance, calls for Russia to isolate itself as much as possible from American financial control, for the establishment of new international financial institutions to parallel those currently dominated by the United States, for protectionist policies, and for accelerated Eurasian economic integration (Glazyev, 2014b).

These preferences reflect a belief that Russia is under threat from the West, and needs to protect itself from Western finance and Western ideology, such as an expansive view of human rights. That in turn implies that Russia must protect its independence, and support a world order founded on sovereign states and respect for the principle of non-interference in the internal affairs of other countries. Such a policy will inevitably conflict with the Western vision of a "liberal" international order, and may therefore oblige Russia either to confront the West or to retreat into isolation. Consequently, Orthodox/Slavophile conservatism to some degree overlaps with civilizational and isolationist conservatism, even if its ultimate ambitions are rather different.

\section{CIVILIZATIONAL CONSERVATISM}

Post-Slavophile Russian philosophy split into two paths-one which continued to believe in universal truth, and another which denied it 
entirely and embraced all-out particularism (Milyukov, 1893, p. 5). The most notable proponent of the latter position was Nikolai Danilevsky, author of the 1867 book Russia and Europe. Together with others, such as Konstantin Leontyev, Danilevsky was responsible for developing the idea that the world was not progressing in its entirety in the same direction towards some universal truth, but rather consisted of distinct civilizations each of which was advancing in its own way towards its own goals. This idea was later adopted by Eurasianist thinkers as well as by post-Soviet international relations analysts such as Alexander Panarin. A study of sources cited in recent years by Russian international relations scholars revealed that the three most cited Russian authors were Danilevsky, Leontyev, and Panarin (Tsygankov, 2017 , p. 585). This type of "civilizational conservatism" is thus very influential.

In Russia and Europe Danilevsky argued that different civilizations (or "cultural-historical types" as he called them) should not be judged by the same standards: "The principles of civilization of one cultural-historical type are not transferable to peoples of another type" (Danilevsky, 2011, p. 113). But while Danilevsky denied that there was any type of universal civilization, he did identify a common good in the form of diversity: the more diversity among human civilizations the better. The danger for humanity was that "one civilization, one culture, will dominate, since this would deprive humanity of one of the necessary conditions for success and perfection-the element of diversity" (Danilevsky, 2011, p. 512).

The obvious threat in this regard was the West and its apparent belief that it constituted the one true civilization. Combating this threat gave Russia a geopolitical mission-to establish a civilization of its own, founded on the idea of Slavdom. Danilevsky therefore supported an imperial project for Russia in which it would take a leading role in uniting the Slav peoples of Europe and eventually create a new federation with its capital in Constantinople.

Danilevsky's civilizational idea was then taken up by Konstantin Leontyev. In an 1876 book entitled Byzantism and Slavdom, Leontyev outlined a theory of a three-stage development of civilizations. 
He argued that organic beings, which included human societies, began simple, gradually became more complex as they grew, then decayed, and finally became simple again. Thus, there were three stages of development: "primary simplicity," "flowering complexity," and "secondary simplicity" (Leontyev, 1876, pp. 72-73). The second stage- "flowering complexity" - represented the peak of a civilization's progress. The liberalism of the West sought to equalize and homogenize everybody and thereby accelerated the onset of "secondary simplicity." Russia, therefore, should resist Westernization and instead support a world with a "flowering complexity" of diverse cultures and systems.

In the aftermath of the Russian Revolution, the idea that Russia formed a civilization distinct from the West was adapted by the first generation of Eurasianists. Eurasianism held that the lands of the former Russian Empire and then of the Soviet Union formed a natural whole. Like Danilevsky and Leontyev, the Eurasianists argued that it was necessary to reject the idea that the Western civilization embodied universal human civilization. As Nikolai Trubetskoi wrote, "the culture of every people must be different. (...) A universal human culture, identical for all peoples is impossible. (...) Thus, the aspiration of each people to create a universal human culture must be rejected. On the contrary, the aspiration of each people to create its own peculiar national culture is completely justified. Any cultural cosmopolitanism or internationalism must be rejected" (Trubetskoi, 1997, pp. 183-185).

Attempts to impose Western civilization on others inevitably produced negative results, Trubetskoi argued. Peoples subject to European colonialization were becoming aware of this and rising up against their oppressors. Russia should put itself at the head of this process and lead the struggle against colonialism (Riasanovsky, 1964, p. 214). This logic provided Russia with a geopolitical task which thereby distinguished civilizational conservatism from its culturally-oriented Orthodox/Slavophile counterpart.

In the late Soviet era, the Eurasianist/civilizational thesis gained an influential proponent in the person of Lev Gumilyov, who argued that ethnic Russians and the steppe peoples, such as Mongols, Kazakhs, and Kyrgyz, were bound together through long-standing complementarities 
and thereby formed what he termed a "super-ethnos" (Gumilyov, 1989, pp. 109-110). In opposition to Western universalism, Gumilyov proposed a separation of sovereign peoples, writing that "the best way to maintain peaceful cooperation between peoples consists in guaranteeing to each of them a territory that each people has the right to administer in its own way, and in which it is permitted to develop itself culturally as it sees fit" (Bassin, 2015, p. 848).

The idea that Russia has a geopolitical mission to support state sovereignty and a multipolar world, and to resist the homogenizing influence of Western liberalism and globalization, has proven very influential in the post-Soviet era. Alexander Panarin, for instance, saw Russia's global role in making it "possible (...) for humanity as a whole to advance into the future not by way of cultural disarmament and depersonalization, but by preserving mankind's cultural-civilizational diversity" (Maslin, 2015, p. 204).

How zealously Russia should pursue this goal is a matter of some debate. For some it is sufficient to "wait patiently" until the United States collapses and a new Russian-led poly-cultural era naturally comes into being (Prokhanov, 2007, p. 47). Others believe that Russia must play a more active role in combating Western hegemony. Among the latter is Alexander Dugin. For Dugin, "the Eurasian project (...) proceeds from the necessity of preserving and developing the identity of peoples and cultures" (Dugin, 2000, p. 219). Standing in the way of this Eurasian project is the Anglo-Saxon-dominated Atlantic world, which poses a significant danger as it is the source of globalizing trends which threaten to homogenize the planet. He complains that, "Spiritually, globalization is the creation of a grand parody, the kingdom of the Antichrist. (...) American values pretend to be 'universal' ones. In reality, they are a new form of ideological aggression against the multiplicity of cultures and traditions still existing in the rest of the world" (Dugin, 2012, pp. 192-193).

On these grounds, Dugin develops some clear policy preferences. Russia, he says, should oppose American-led globalization and forge an alliance with other nations to defend a poly-cultural world respecting a diversity of civilizations. This alliance should include "Muslims and 
Christians, Russians and Chinese, both leftists and rightists, the Hindus and the Jews" (Dugin, 2012, p. 193). As a Eurasian civilization, whose past has been influenced by all these cultures, Russia is ideally placed, he argues, to take the lead.

Civilizational conservatism seeks to replace globalization with a process of regionalization, or as Alexander Dugin calls it "regional globalization," creating a world with a number of regional power blocs based on civilizational commonalities (Dugin, 2012, p. 116). This implies regional, rather than global, economic integration, resulting in several economic conglomerations, such as North America, the European Union, and a much expanded and enhanced Eurasian Economic Union, each of which would erect protective barriers against one another. Broader and deeper Eurasian integration is thus a prime geopolitical objective in civilizational conservative thought.

Dugin's brand of civilizational thinking tends towards a view of the future somewhat resembling Samuel Huntington's Clash of Civilizations, at least as far as the inevitability of a clash between the Eurasian and Anglo-Saxon civilizations is concerned. There is, however, another approach which stresses dialogue and cooperation, rather than competition, between civilizations. The most notable example of this is Vladimir Yakunin's Dialogue of Civilizations (research institute, which hosts an annual conference in Rhodes featuring hundreds of delegates from around the world). According to the institute's website, "its vision is rooted in the understanding that an open, mutually respectful and equitable dialogue is the fundamental prerequisite for effective cooperation and partnership between civilizations" (DOC Research Institute). Thus, while civilizational conservatism can produce a confrontational approach to international politics, this is not necessarily the case.

The discourse of civilizational conservatism has some appeal outside of Russia among states which wish to protect their own sovereignty and which desire a more multipolar world. In particular, it provides common ground on which Russia and rising states such as China and India can work together to put into effect a different vision of the international order as an alternative to that currently propounded by 
the United States and its Western allies. To the extent that this is so, this does indeed make Russia an "international conservative power."

That said, it would be wrong to make too much of this. While many states sympathize with the civilizational discourse, there is little evidence that they are willing to accept Russian leadership, let alone create the sort of formal alliance against the West favored by some Eurasianists. Attempts to put something like a Eurasianist policy into practice, through institutions such as the Eurasian Economic Union, the Shanghai Cooperation Organization, and the Collective Security Treaty Organization, have to date had limited success. While willing to cooperate on specific issues, ex-Soviet states are wary of structures which might subordinate them to the Russian Federation. They also for the most part want good relations with the West. The extent to which Russia's promotion of a poly-cultural, multipolar world of sovereign states truly makes it a "conservative power" is therefore somewhat debatable.

It is also worth noting that civilizational conservatism is in some respects quite radical. A Russia which was an international conservative power according to the civilizational definition would find itself committed to a major reworking of the international system. If this was to follow the model of the Dialogue of Civilizations, this reworking might develop peacefully. If, however, it were to follow Dugin's more confrontational approach, it would run the risk of producing a longterm and bitter political conflict with Western powers. The radicalism and possible costs of civilizational conservative philosophy thus limit its attractiveness even among Russian conservatives.

\section{ISOLATIONIST CONSERVATISM}

There is a long tradition of Russian conservatives who have thoroughly rejected the idea that Russia has a global mission. This can be seen as far back as 1812, when Russia's leaders debated what to do after the French army had been driven out of Russian territory. Some favored pursuing the French and "liberating" Europe. Others argued that the Russian army should stop at its own borders and that Russians should not shed any of their blood for Europeans. Among the latter was Alexander I's State Secretary, Admiral Alexander Shishkov, who may rightly be 
considered one of the founding fathers of Russian conservatism. To Shishkov what mattered were Russian interests, not grandiose ideas of international mission. "[War] be damned!" he wrote, "If you killed all scholars (...) all people would be turned into wicked boors; whereas if you killed all soldiers (...) all people would live in peace" (Martin, 1997, p. 139).

Shishkov's view was an example of the "isolationist" strand of Russian conservatism. In the 1860s, the conservative newspaper Vest' espoused a similar philosophy, publishing under the banner "Russia for the Russians!" This slogan was a reaction to the Pan-Slavism proposed by many of the Orthodox/Slavophile and civilizational conservative tendencies. As far as Vest' was concerned, the fate of peoples such as the Bulgarians was none of Russia's concern and certainly not worth the cost of war. "Sacrificing Russian interests for the Slavs? No, and a thousand times no! Russia for the Russians! That is our banner," the newspaper declared (Ivanov, 2015, p. 34).

Perhaps the most famous conservative exponent of this point of view was Alexander Solzhenitsyn. According to Solzhenitsyn, the mark of a nation was its "inner development." Due to the spiritual problems Russia faced as a result of decades of communist rule, the country needed to step away from external affairs. He wrote: "Just as a family, in which there has been a great misfortune and shame, tries to isolate itself from everybody for a bit, and to work out its grief on its own, so too must the Russian people be alone with itself, without neighbors and guests; concentrating on its inner tasks: on healing its soul, educating its children, and sorting out its own house" (Solzhenitsyn, 1995, p. 84).

In line with this logic, Solzhenitsyn argued that it would be best for Russia if the non-Slavic republics of the Soviet Union seceded from the Union, leaving only a core of Russia, Belarus, and Ukraine. In fact, it might be beneficial if even parts of Ukraine left, too. "We do not have the strength for an empire, we don't need it," Solzhenitsyn wrote. "By separating twelve republics (...) Russia will liberate itself for a precious inner development" (Solzhenitsyn, 1995, p. 542). Solzhenitsyn thus firmly abjured the imperial ambitions and global missions favored by other conservatives mentioned above. 
Isolationism continues to attract some Russian conservatives today. The most important figure in this regard is the late Vadim Tsymbursky, who developed a theory of what he called "geopolitical conservatism" (Tsymbursky, 2015, pp. 41-44). Tsymbursky rejected the aggressive ideas of the Eurasianists, and instead proposed the idea of "Island Russia." In Tsymbursky's view, Russia would not benefit from challenging the U.S.-dominated world order, as the disintegration of that order would bring chaos in its wake. Instead Russia should focus on being a regional power and ensure peace with the West by means of a buffer zone in the form of "limitrophe states," such as Ukraine. Island Russia could then focus on its internal development. The West and Russia should recognize each other as distinct civilizations, political centers towards which other states would gravitate. Russia should seek to preserve what he called a "one and a half polar world," in which the United States constituted the only large civilization but there were also several smaller regional ones, including Russia (Mezhuev, 2017a).

In the 1990s and early 2000s, Tsymbursky had a strong influence on a group known as the "young conservatives," which included thinkers such as Boris Mezhuev, Yegor Kholmogorov, and Mikhail Remizov. Among them, Mezhuev has done the most to propagate Tsymbursky's ideas, arguing in favor of what he calls "civilizational realism" based on Tsymbursky's concepts (Mezhuev, 2017b). Like Tsymbursky, Mezhuev rejects the idea, favored by civilizational conservatives such as Dugin and some Orthodox/Slavophile conservatives such as Glazyev, that Russia should seek to undermine U.S. global hegemony. But he is likewise skeptical of Orthodox/Slavophile conservatives' belief that Russia will be able to find allies in the West, and did not share the optimism of some Russian conservatives, such as Dmitry Drobnitsky, that the election of Donald Trump as president of the United States would allow Russia and America to strike a "grand bargain" which would resolve their differences (Mezhuev, 2017b). According to Mezhuev's philosophy of civilizational realism, the United States and Russia have no option but to recognize each other's zones of influence and let each other be. 
Kholmogorov, meanwhile, concurs that "Russia is an island" and praises Tsymbursky for "showing the necessity of Russian isolationism" (Kholmogorov, 2016, pp. 7-8). Kholmogorov's approach is, however, somewhat less isolationist than that of Mezhuev. This reflects his connections with Orthodox/Slavophile conservatism, which make him more sympathetic to the view that Russia is a European power rather than a separate civilization. "Let's be honest," he writes, "both our government and most of our society want to be part of Europe" (Kholmogorov, 2016, p. 143). He is also somewhat more confrontational than others on the isolationist wing, showing a willingness to push back against perceived American intrusions into "Island Russia" and the limitrophe states. Notably, Kholmogorov believes that Russia should support the rebellions in Eastern Ukraine, and propounds what he calls "offensive isolationism"-i.e. an overall isolationist policy combined with counterattacks against intrusions into Island Russia's protective zone. "This urge to counterattack," he says, "is a reaction to the feeling that far is enough, one step further and we'll be eaten, destroyed" (Kholmogorov, 2017).

Remizov takes yet another approach. He writes that, "We simply do not have the resources to legitimize an imperial/super-national power," adding that, "We have no need to either dispute or lighten the U.S.A.'s hegemonic burden, turning it into a sparring partner in the global ring" (Remizov, 2016, p. 366). Remizov cites Tsymbursky as saying that Russia's objective should be "a pre-imperial cultural geographic core with a stable and absolute predomination of Russians" (Remizov, 2016, p. 122). This reflects Remizov's ethno-nationalist inclinations, which lead him to be more skeptical than civilizational conservatives of Eurasian integration. While not rejecting it, he would prefer that Central Asia states not be included in any such integration project as this would likely lead to a further influx of immigrants from those countries into Russia. In particular, Remizov argues against the inclusion of Kyrgyzstan in the Eurasian Union (2016, p. 373). Instead of looking for immigrants from Central Asia, he says, Russia should be seeking to draw in ethnic Russians from former Soviet states, and making it easier for them to live in Russia and receive Russian passports (2016, pp. 285-288) 
Isolationist conservatism is popular among a comparatively narrow circle of Russian intellectuals. To some extent it is linked to Russian ethno-nationalism, and thus rejects the idea that Russia is a Eurasian civilization. Consequently, isolationist conservatives have little interest in integration with the Central Asian republics. Its adherents favor an inward orientation and express a willingness to accept a peaceful international modus vivendi based on the principle of the recognition of mutual difference and non-interference. In practical terms, this would not preclude Russia from becoming involved in its near abroad, but would preclude actions further afield, such as the current military campaign in Syria. It implies abandoning Russia’s pretensions to be a great power. This puts it firmly at odds with state/official conservatism, for which great power status has long been an important priority.

\section{STATE/OFFICIAL CONSERVATISM}

Elements of both Orthodox and civilizational conservatism (although not isolationist conservatism) can be found in official discourse. For instance, in his annual press conference on December 23, 2016, President Putin made direct reference to the possibility of using "traditional values" as a source of soft power, saying: "It is good that there are people who sympathize with our views on traditional values because this forms a good foundation on which to build relations between two such powerful countries as Russia and the United States, build them on the basis of our peoples' mutual sympathy" (Putin, 2016).

Meanwhile, the 2016 Foreign Policy Concept declares: "The cultural and civilizational diversity of the world and the existence of multiple development models are clearer than ever. Tensions are rising due to disparities in global development (...) This competition (...) is increasingly gaining a civilizational dimension in the form of dueling values. Against this backdrop, attempts to impose values on others can stoke xenophobia, intolerance and conflict in international affairs, leading ultimately to chaos" (Foreign Policy Concept, 2016).

This passage indicates the degree to which civilizational conservatism has now become mainstream. Nevertheless, it is not obvious that Russian leaders fully accept either the Orthodox/ 
Slavophile or the civilizational models. Certainly, the ambitious Eurasianist schemes proposed by the likes of Alexander Dugin have never gained official acceptance. And despite the creation of the Eurasian Economic Union, it does not appear that senior officials actually believe that Russia is a distinct Eurasian civilization. Most notably, Vladimir Putin has repeatedly referred to Russia as a "European" country." In October 2017, for instance, he told a group of students that, "You have said Russia is a vast territory and it is indeed so-from its western to eastern borders, it is a Eurasian space. But as regards culture, even language, language group and history, this is all undoubtedly a European space as it is inhabited by people of this culture" (Putin, 2017). As with the statements on "traditional values" one should be careful about reading too much into official references to civilizations. Civilizational discourse provides a means of justifying Russian state leaders' preference for a multipolar order founded on the principle of state sovereignty. But that preference existed well before the civilizational discourse became common.

Official conservatism is more pragmatic and moderate than Orthodox/Slavophile and civilizational conservatism, and always has been. In 1833, the Minister of Popular Enlightenment, Count Sergei Uvarov developed the ideology of "official nationality," whose slogan "Orthodoxy, Autocracy, Nationality" has ever since been associated with Russian conservatism (Repnikov, 2014, p. 19). If the philosophers of Orthodox and civilizational conservatism have largely been concerned with the first and last elements of Uvarov's trio, the Russian state and its rulers have tended to be concerned primarily with the second-autocracy, perhaps better expressed in its modern form as "statehood" (gosudarstvennost'). In other words, the primary considerations of the Russian state have never been ideological (Orthodoxy or nationalism) but have been maximizing the strength and stability of the state. In international terms this has meant seeking recognition from the international community of Russia's status as a great power.

Interpretations of state interests have inevitably been colored by the prevailing ideological constructs of the time, but with a few 
exceptions (such as Alexander I's Holy Alliance, and the first few decades of Soviet rule) it is difficult to make an argument that in the realm of international affairs ideology has been a primary mover of state policy. Moreover, in so far as Russia has attempted to adopt an imperialistic or messianic policy of the sort envisioned by some of the philosophers discussed above, it has more often been under the rule of leaders considered reformist or revolutionary (such as Alexanders I and II, and Lenin) than under those considered conservative (such as Nicholas I, Alexander III, or Leonid Brezhnev), the latter being focused on the maintenance of stability.

Nicholas I, for instance, was no fan of the imperial ambitions of the Pan-Slavists, which he denounced as founded on a revolutionary idea which encouraged rebellion against established governments, threatened the principle of states' territorial integrity, and undermined the foundations of the entire international order (Lincoln, 1978, p. 164). Nicholas opposed what nowadays is called "regime change" and supported state sovereignty and a stable international system. When he did finally overcome his reluctance to intervene militarily in the affairs of other states (in Hungary in 1849) it was not to overthrow a governing regime but rather to prevent it from being overthrown.

The parallel with the current Russian government's intervention in Syria is quite striking. The modern Russian state shows a strong preference for "stability," a word used repeatedly by senior officials such as President Vladimir Putin and Foreign Minister Sergei Lavrov. This long predates the post-2012 "conservative turn" in Russian politics. For instance, on September 1, 2001, Putin remarked that "the general aim of Russia's external policy is to create a situation around our country which would help solve internal economic and internal political tasks. This presupposes stability in the world" (Putin, 2001).

The preference for stability can be seen much later in the 2016 Foreign Policy Concept of the Russian Federation, which uses the word "stability" no fewer than 24 times (Foreign Policy Concept, 2016). The Foreign Policy Concept can be seen as a quintessentially conservative document as it eschews proposing fundamental changes in the international order, but instead speaks of "maintaining and 
strengthening" the systems and institutions which already exist. For instance, the Concept states that "the UN should maintain its central role in regulating international relations" and that the Russian Federation advocates "maintaining and strengthening international rule of law" (Foreign Policy Concept, 2016).

In official discourse and policy, therefore, Russia is the defender of stability. It claims to seek to preserve the existing international order against efforts by Western powers, most notably the United States, to revise it (for instance, Lavrov, 2019). Official discourse thus eschews the more revisionist ideas of conservative intellectuals. According to Richard Sakwa, Russia is therefore best understood as a "conservative status quo power" (Sakwa, 2015, p. 116), or alternatively a "neorevisionist power"-neo-revisionist in the sense that it is trying to revise the revisions made by the United States and return things to the way they were (Sakwa, 2015, p. 31).

As the discussion above shows, the differences between the various strands of Russian conservatism are quite profound. Some conservatives view Russia's mission in the world as primarily cultural. Others view it as geopolitical. Others still renounce the idea of mission entirely and believe that Russia should focus on its own internal development. Some conservatives want Russia to take the lead in radically reshaping the global order. Others see themselves instead as defending the international system against the attempts of other powers to revise it. One must be careful about talking of Russia's emergence as an international conservative power, as that could mean many different things depending on what type of conservatism is being discussed.

Moreover, it is noteworthy that the idea of Russia as a conservative power is promoted by Russia's enemies as much as by its friends. A conservative Russia is a powerful bogeyman which can be used to mobilize liberal public opinion in the West. It is no coincidence, therefore, that accusations that Russia is waging information warfare against the West are often accompanied by complaints about Russian support for conservative populists in Europe, about the propagation of 
conservative values through Russian media institutions such as RT, and so on. But like so much of the discussion about information warfare, these complaints need to be taken with a large pinch of salt. Ascribing the rise of Western populism to Russian influence almost certainly grants Russia far more power than it actually has.

In any case, the connection between conservative ideology and state practice is weaker than is often assumed. In 2001, then Russian Foreign Minister Igor Ivanov remarked that, "Russian diplomacy has always succeeded when guided by realistic, pragmatic considerations and failed when dominated by imperial ideology and messianic ambitions" (Bouveng, 2010, p. 1). It would appear that this remains the prevailing attitude among top state officials. Although much has changed since 2001, the preference for a stable, multipolar international order, founded on the UN Charter and the principle of state sovereignty, has not. In broad terms, over the past twenty years Russian foreign policy has remained remarkably consistent. This suggests that the driving force of Russian actions on the international scene remains a pragmatic understanding of Russian interests rather than any passing ideological considerations.

As noted at the start of this essay, conservatism can be seen either as a fully-fledged ideology or as a "natural attitude." Orthodox/Slavophile, civilizational, and isolationist conservatism may all be seen as forms of ideological conservatism. By contrast, state/official conservatism is closer to a natural attitude, favoring stability and gradual change over revolutionary shocks. Over the past twenty years, the Russian state has consistently displayed this attitude, while complaining that the West has been revising the international order in a revolutionary manner. From this one can conclude that Russia is indeed an international conservative power, just not in the ideological sense that people often believe it is. Whether this conservative attitude will serve Russia well in the long term is something that remains to be seen. 


\section{References}

Bassin, M., 2015. Lev Gumilyov and the European New Right. Nationalities Papers: The Journal of Nationalism and Ethnicity, 43(6), pp. 840-865.

Blinova, E., 2018. Russia Has Emerged as an International Conservative Leader - Academic. Sputnik, 20 October. Available at: <https://sputniknews. com/analysis/201810201069040138-russia-eu-us-conservatism/> [Accessed 21 September 2019].

Bouveng, R., 2010. The Role of Messianism in Contemporary Russian Identity and Statecraft. $P h D$ Thesis, Durham University. Available at: $<$ http://etheses.dur. ac.uk/438/1/K.R.Bouveng_thesis.pdf?DDD35+> [Accessed 23 September 2019].

Buchanan, P., 2013. Is Putin One of Us? Patrick J. Buchanan Official Website, 17 December. Available at: <https://buchanan.org/blog/putin-one-us-6071> [Accessed 21 September 2019].

Burgess, J., 2017. Holy Rus': The Rebirth of Orthodoxy in the New Russia. New Haven: Yale University Press.

Danilevsky, N. Ia., 2011. Rossiya i Evropa: vzglyad na kul'turnye i politicheskie otnosheniya slavyanskogo mira $k$ germano-romanskomu [Russia and Europe: A View on Cultural and Political Approaches of the Slavic World Towards the Germanic-Romance World]. Moscow: Blagoslovenie.

DOC Research Institute. About DOC. Available at: <https://doc-research.org/ about-us/> [Accessed 13 January 2020].

Dugin, A., 2000. Osnovy geopolitiki: geopoliticheskoe budushchee Rossii. [The Foundations of Geopolitics: The Geopolitical Future of Russia]. Moscow: Arktogeia.

Dugin, A., 2012. The Fourth Political Theory. London: Artkos Media.

Engström, M., 2014. Contemporary Russian Messianism and the New Russian Foreign Policy. Contemporary Security Policy, 35(3), pp. 357-379.

Evans, A., 2015. Ideological Change under Vladimir Putin in the Perspective of Social Identity Theory. Demokratizatsiya: The Journal of Post-Soviet Democratization, 23(4), pp. 401-426.

Fedulov, A., 2015. The Phenomenon of the 'Russian Soul' as a Reflection of Traditional Conservatism: New Theoretical and Methodological Approaches and Ordinary Perception of Conservatism. Mediterranean Journal of Social Sciences, 6(6), pp. 113-121. 
Foreign Policy Concept, 2016. Foreign Policy Concept of the Russian Federation. Available at: <https://www.mid.ru/en/foreign_policy/official_documents/-/asset_ publisher/CptICkB6BZ29/content/id/2542248> [Accessed 14 January 2020].

Freeden, M., 1996. Ideologies and Political Theory: A Conceptual Approach. Oxford: Clarendon Press.

Glazyev, S. Iu., 2014a. Konservatizm i novaya ekonomika [Conservatism and New Economy]. Tetradi po Konservatizmu [Workbooks on Conservatism], 1, pp. 61-67.

Glazyev, S. Iu., 2014b. Predotvratit' voinnu-pobedit' v voīne (doklad Isborskomu klubu) [To Prevent the War Is to Win the War (Report to the Izborsky Club)]. Izborskī klub, 30 September. Available at <https://izborsk-club.ru/3963> [Accessed 13 January 2020].

Gorokhov, A.A., 2016. Konservatizm v Rossii i osobennosti russkoī konservativnō̄ sotsial'no-politicheskō̄ mysli pervoī poloviny XIX veka [Conservatism in Russia and Characteristics of Russian Conservative SocioPolitical Thought of the First Half of 19th Century]. Tetradi po Konservatizmu [Workbooks on Conservatism], 2, pp. 125-150.

Grenier, P., 2015. The Varieties of Russian Conservatism. The American Conservative, 19 June. Available at <https://www.theamericanconservative.com/ articles/the-varieties-of-russian-conservatism/> [Accessed 21 September 2019].

Gumilev, L.N., 1989. Etnogenez i biosfera zemli [Ethnogenezis and the Earth's Biosphere]. Leningrad: Leningrad University Press.

Huntington, S., 1957. Conservatism as an Ideology. American Political Science Review, 51(2), pp. 454-473.

Ivanov, A.A., 2015. Lozung "Rossiya dlya russkih" v konservativnoī mysli vtoroī poloviny XIX veka [The "Russia for the Russians" Slogan in the Conservative Thought of the Second Half of the 19th Century]. Tetradi po Konservatizmu [Workbooks on Conservatism], 4, pp. 34-42.

Kholmogorov, E., 2016. Revansh russkoī istorii [The Revanche of Russian History]. Moscow: Knizhny mir.

Kholmogorov, E., 2017. Interview with Egor Kholmogorov. Irrussianality, 18 November. Available at: <https://irrussianality.wordpress.com/2017/11/18/ interview-with-egor-kholmogorov/> [Accessed 13 January 2020].

Lavrov, S., 2019. The World at a Crossroads and a System of International Relations for the Future. Russia in Global Affairs, 17(4), 2019; DOI: 
10.31278/1810-6374-2019-17-4-8-18; Available at: < https://eng.globalaffairs. $\mathrm{ru} /$ articles/world-at-a-crossroads-and-a-system-of-international-relations-forthe-future/

Leontyev, K., 1876. Vizantizm i slavianstvo [Byzantinism and Slavdom]. Moscow. Lincoln, B., 1978. Nicholas I: Emperor and Autocrat of all the Russias. Bloomington: Indiana University Press.

Lloyd, J. and Litinova, D., 2018. The Reality of Russian Soft Power. The American Interest, 21 March. < https://www.the-american-interest.com/2018/03/21/ putins-soft-power/> [Accessed 20 September 2019].

Makarychev, A. and Yatsyk, A., 2014. A New Russian Conservatism: Domestic Roots and Repercussions for Europe. Notes Internacionals CIDOB, 93, pp. 1-6.

Martin, A., 1997. Romantics, Reformers, Reactionaries: Russian Conservative Thought and Politics in the Reign of Alexander I. DeKalb: Northern Illinois University Press.

Maslin, M.A., 2015. Klassicheskoe evraziīstvo i ego sovremennye transformatsii [Classical Eurasianism and Its Modern Transformations]. Tetradi po Konservatizmu [Workbooks on Conservatism], 4, pp. 201-210.

Mezhuev, B., 2017a. Island Russia and Russia’s Identity Politics. Russia in Global Affairs, 15(2). Available at <http://eng.globalaffairs.ru/number/Island-Russiaand-Russias-Identity-Politics-18757> [Accessed 20 September 2019].

Mezhuev, B., 2017b. In Russia, It's the Realists vs. the Ethno-Nationalists. The American Conservative, 10 May. Available at <http://www. theamericanconservative.com/articles/in-russia-its-the-realists-vs-the-ethnonationalists/> [Accessed 20 September 2019].

Milyukov, P., 1893. Razlozhenie slavianofil'stva: Danilevskī, Leont'ev, Vl. Solov'ev [The Decay of Slavophilism: Danilevsky, Leontiev, Vladimir Solovyov]. Moscow: Tipo-lit. Vysochaishe utver. T-va I.N. Kunshnerev.

Minakov, A. Iu., 2011. Russkii konservatizm v pervoi chetverti XIX veka [Russian Conservatism in the First Quarter of the 19th Century]. Voronezh: Izdatel'stvo Voronezhskogo gosudarstvennogo universiteta.

Narochnitskaya, N., 2015. Russkii kod razvitiya [Russia's Development Code]. Moscow: Knizhny mir.

Polyakov. L., 2014. Shans obedineniya vlasti i naroda na odnoì tsennostnoī osnove [The Chance of Unity of Authorities and the People on a Common 
Value Foundtion]. Tetradi po Konservatizmu [Workbooks on Conservatism], 1, pp. 41-49.

Prokhanov, A., 2007. Simfoniia "Pyatoi Imperii" [The Symphony of the 'Fifth Empire']. Moscow: Eksmo.

Putin, V.V., 2001. Interview with the Finnish Newspaper Helsingin Sanomat. 1 September 2001. Available at: <http://kremlin.ru/events/president/ transcripts/21315> [Accessed 23 September 2019].

Putin, V.V., 2016. Vladimir Putin's Annual News Conference. Kremlin.ru, 23 December. Available at: <http://en.kremlin.ru/events/president/news/53573> [Accessed 23 September 2019].

Putin, V.V., 2017. Vstrecha s uchastnikami XIX Vsemirnogo festivalya molodezhi i studentov [Meeting with the Participants of 19th World Festival of Youth and Students]. Kremlin.ru, 14 October. Available at:<http://kremlin.ru/ events/president/transcripts/55842> [Accessed 23 September 2019].

Rabow-Edling, S., 2006. Slavophile Thought and the Politics of Cultural Nationalism. Albany: State University of New York Press.

Remizov, M., 2016. Russkie i gosudarstvo [The Russians and the State]. Moscow: Eksmo.

Repnikov, A.V., 2014. Konservativnye modeli Rossī̄skoi gosudarstvennosti [Conservative Models of Russian Statehood]. Moscow: Rosspen.

Riasanovsky, N.V.,1964. Prince N.S. Trubetskoi's "Europe and Mankind". Jahrbücher für Geschichte Osteuropas, 12(2), pp. 207-220.

Shchipkov, A.V., 2014. Tipologiya napravlenī̄ konservativnoī mysli v sovremennoī Rossii [Typology of Conservative Thought Schools in Modern Russia]. Tetradi po Konservatizmu [Workbooks on Conservatism], 2(1), pp. 114117.

Shchipkov, A.V., 2017. Levyī konservatizm [Left Conservatism]. In: A.V. Shchipkov (ed). Po drugomu: sbornik stateī o traditsii i smene ideologicheskogo diskursa [In a Different Way: Collection of Articles on Tradition and Change of Ideological Discourse]. Moscow: Abris.

Solzhenitsyn, A., 1995. Publitsistika $v$ treh tomah [Social and Political Writings in Three Volumes], Vol. 1. Yaroslavl': Verkhne-Volzhskoe Knizhnoe Izdatel'stvo.

Stroop, S., 2016. A Right-Wing International? The Public Eye, Winter, pp. 4-10. 
Trubetskoi, N.S., 1997. Ob istinnom i lozhnom natsionalizme [On True and False Nationalism]. In: O.S. Shirokov (ed). Iskhod k vostoku [Exodus to the East], pp. 171-195. Moscow: Dobrosvet.

Tsygankov, A.P., 2017. In the Shadow of Nikolai Danilevsky: Universalism, Particularism, and Russian Geopolitical Theory. Europe-Asia Studies, 69(4), pp. 571-593.

Tsymbursky, V.L., 2015. Osnovaniya rossī̄skogo geopoliticheskogo konservatizma [Foundations of Russian Geopolitical Conservatism]. Tetradi po Konservatizmu [Workbooks on Conservatism], 1, pp. 41-44

Whitmore. B., 2013. Vladimir Putin, Conservative Icon. The Atlantic, 20 December. Available at: <https://www.theatlantic.com/international/ archive/2013/12/vladimir-putin-conservative-icon/282572/> [Accessed 20 September 2019]. 